\title{
Achieving Competitive Advantage in Economic Crisis
}

\author{
Salem Ahmad Alrhaimi ${ }^{1}$ \\ ${ }^{1}$ College of Administrative and Financial Sciences, Irbid National University, Jordan \\ Correspondence: Salem Ahmad Alrhaimi, College of Administrative and Financial Sciences, Irbid National \\ University, P.O Box: 2600, Zip Code: 21110, Jordan. Tel: 962-799-192-974. E-mail: salemalrahimy@ gmail.com; \\ salemalrahimy@yahoo.com
}

Received: June 23, 2015

Accepted: July 1, 2015

Online Published: August 25, 2015

doi:10.5539/ijef.v7n9p287

URL: http://dx.doi.org/10.5539/ijef.v7n9p287

\begin{abstract}
This paper seeks to encourage potential and existing entrepreneurs to do business, even in economic crisis and global recession. The global economic crisis strongly affected less developed areas, especially small entrepreneurs in these areas. In such conditions there is not much space left for successful entrepreneurship, entrepreneurs are forced to search new opportunities, and to do businesses with higher risks. They must have a modern approach to entrepreneurship, which tries to discover new opportunities in an innovative way. The paper shows that crisis and recession can provide new opportunities that need to be detected at the right time Competitive advantage may be gained if the entrepreneur is able to offer something valuable and important to the market, and if it differs from the competition in a way that offers better quality. In addition, there must be many other sources of competitive advantages which should support the main source of competitive value. The aim of the paper is to help entrepreneurs to find sources of competitive advantage in time of economic crises.
\end{abstract}

Keywords: doing business, economic crisis, competitive advantage

\section{Introduction}

The goal of every company is to achieve sustainable profitability, and the goal of every business is profit. In order to achieve this there must be a basic orientation of the company and its operations. Through the realization of defined goals potential profit potential will be converted into real, even in times of economic crisis.

Every successful business brings a contribution to social welfare. However, a low level of agreement between theoreticians and practitioners about what social entrepreneurship is exists (Trivedi \& Stokols, 2011). In fact, Marković et al. (2011) argued that the whole business environment changes, and accordingly to these changes the organization and structure of the company changes too. Fast flow of information becomes a key point of any business success, and when technological solutions are well-established then the business mostly depends on abilities and skills of entrepreneurs. Eeckhoudt et al. (2011) debated that the existence of high correlation between risks should increase the value of information. However, effects of recession had a significant impact, but entrepreneurs shall not be discouraged to invest in businesses. Crisis management is a systemic approach that engages the whole organization in efforts to avert crises that may affect the firm. Pearson (2002) argued that optimal crisis management is crisis aversion, but there is no way to ensure that an organization will escape economic crises.

\section{New Business Opportunities in Economic Crises}

In economic crisis, when the business environment seems to be confined, and when it seems that it would be extremely unreasonable to search new business opportunities, a new business opportunity always exists. In addition, successful companies with business tradition exist at the market, what may discourage potential small businesses to establish and develop new businesses. But in the other side, the belief that there is always a better, more creative and more innovative way to do things in business encourages. New business opportunities open the way to do something different and better, and innovations allow doing business activities differently and better. Wickham (2001) argued that no one can defend from creativity and innovation in a long-term, what leads to discovery of new business opportunities. In the situation when the industry is declining, and when all significant industrial sectors are declining, a new business must be highly innovative, usually offering high quality products, and/or related services, which are developed and adopted to new business. 


\section{Lifetime of Business in Crisis}

The analysis of business lifetime is based on analysis of the lifecycle of the product/service in the market, and represents a period when a new product/service does not face significant competition in the market. (Levy, 1998). For any product, especially for market-oriented innovative products, there is an opportunity for market exploitation, even in economic crises. But, the business opportunity is constantly narrowing, and the lifetime of the product is shortened, competition grows, which appearance is increasingly frequent, and additionally the economic crisis weakened the market. In the other side, to get knowledge to be produced by markets may be highly innefficient (Stiglitz, 2010). In some cases, one can succeed in doing so, but the societal costs of using a market mechanism may be large. It is worth to mention that the SME sector is the most dynamic sector, and the effects of the crisis first are reflected in this sector. Businesses in the SME sector depend on well-functioning state institutions to build a good invstment climate and deliver basic services competently (Goldin \& Reinert, 2012).

\section{Sources of Competitive Advantages in Economic Crisis}

A key question is why some companies gain a long-term competitive advantage and others do not. One view focuses on internal resources and capabilities as sources of sustained competitive advantage for companies (Zhao et al., 2014). The sources of competitive advantage in economic crisis could be costs, knowledge, relations, and structure (Dollinger, 1999). The main approach to sources of possible competitive advantages is orientation to strategic capabilities and competence of the enterprise. In times of economic crisis, we will not only witnesses of an impressive growth of SMEs, but also large enterprises must restructure in order to survive in the market. SMEs are key generators of employment, and drivers of innovation and growth. In EU they count over $99 \%$ of all enterprises (OECD, 2009). SMEs can increase employment and economic output, which drives the economy out of the crisis (Krugman, 2012). Given their importance in all economies, they are essential for economic recovery.

Entrepreneurs and people who want to establish new enterprises or take over existing companies need a start-up equity. To boost establishment and acquisitions, the required volume of incentives is higher than by usually saving incentives (Brūmerhoff, 1996). Such an incentive could be more favorable lending terms, particularly lower interest rates than those that exist in the market. In many cases, it turned out that companies that have used some of support programs are more dynamic then other companies which did not use incentives. Ideas are the most powerful influence on development (Goldin \& Reinert, 2012). Ideas are the transmission of distinctive intellectual constructs in any field that can have impact on production systems, management practices, and technological trends. Ideas are fundamental to the future progress of development (Meier \& Stiglitz, 2001).

\subsection{Effects of Delayed Market Entry}

Many management books talk about adoption to the market and business environment, which are changing. But, if you are adopting you react, you are waiting to see what will happen, and then you adjust (Adizes, 2009). It can work if the change is very slow or at least so slow that your reaction is faster. While you adjust to the environment and to the market it could change again, and you always will lag behind. Developing a product can require five to ten times the time, expense and effort required to produce a device (Phillips, 2001). It also requires market orientation. In the other side, if the crisis is a problem that is not solved, and is waiting to be solved, then the enterprise must address problems that arise proactively, and if the company addresses the problems successful they will not turn into a crisis. The longer you wait the problem becomes more complex and difficult to solve. The crisis persists, businesses are shutting down, employment is falling down, and the result is that the demand falls, and crisis threatens to grow into a global depression. 


\section{Cash flow}

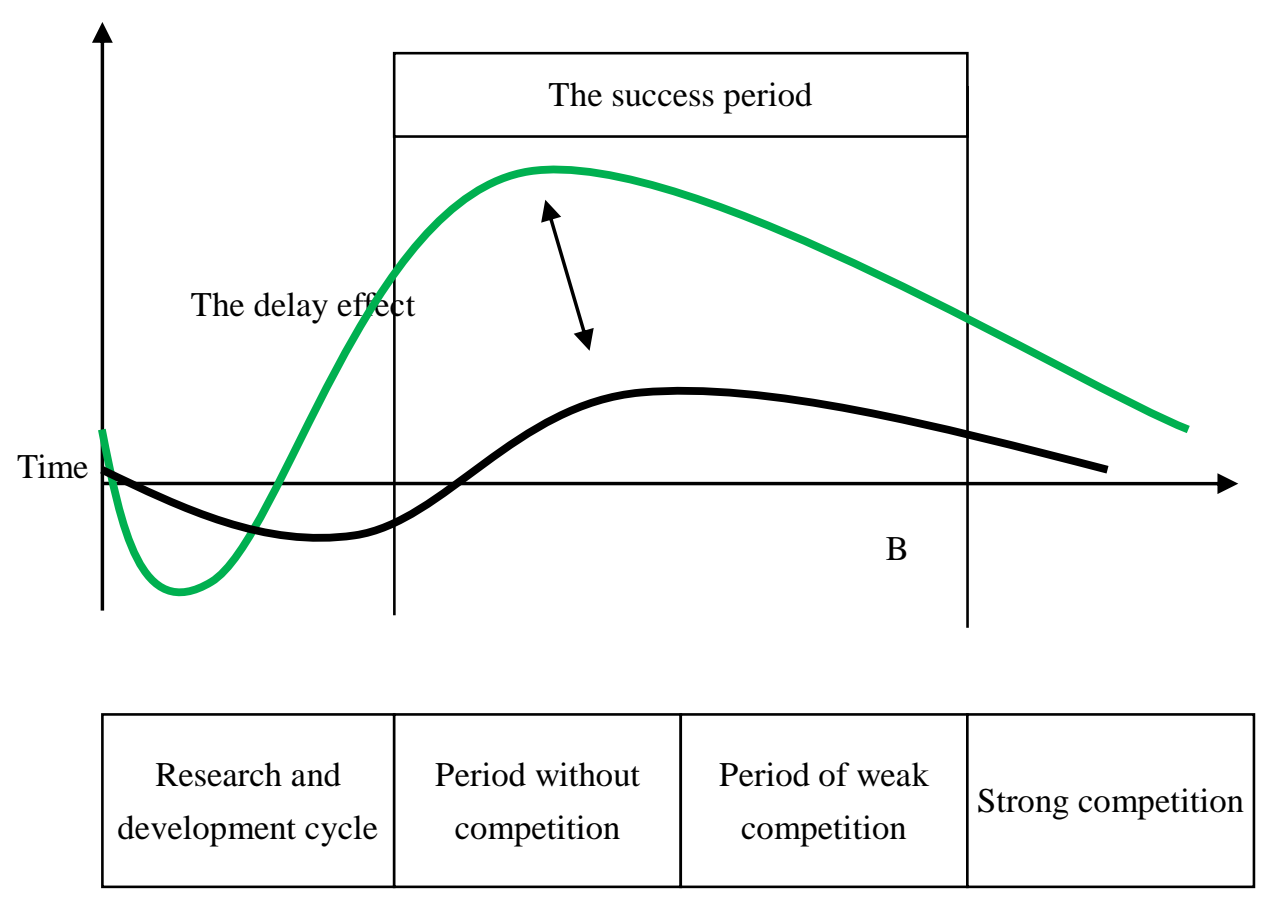

Figure 1. Effects of delayed market entry

At the picture can be clearly seen the effect of delayed market entry in a particular market. Enterprise B is late in reacting in the field of research and development. As a consequence, the enterprise is constantly faced with competition, and with poor utilization of business opportunities. On the other hand, company B has reacted on time, and took in the right way the business opportunity in the market, especially in the period without competition.

\section{For Current and Future Entrepreneurs}

To succeed in business today, it is necessary to redeem a drain flock. (Riderstrale \& Nordstrom, 1999). It takes an innovative business, different, unpredictable and full of surprises. It takes also a new paradigm ofmanagement theory, a universal theory that is independent of culture, economically neutral and non-elitist, which leads to superior economic performance (Adizes, 2011). The management process is too complicated for any individual to be able to become excellent in each of its segments. Successful management is a team process. True, one leader, primus inter pares, but without others, its individual decisions can take the entire organization in the loss. Do not forget to create a crisis plan with your team, and incorporate it into your operations manual (Fredricksen, 2012).

Do not get inspirited from Asian models (China), where the success of the economy is paid almost with slave-like position of employees, who meet high standards with minimum wages. Get inspired from the development model of western countries. Invest in research and development, create high-quality and innovative products, develop services, and smoothly shift to the service sector, offering demanding and specific services.

To cope with challenges, executives will be required to redefine their managerial mind-set (Rhodes \& Stelter, 2010). They will need to reexamine the context in which they make decisions and act as leaders. A leader in economic crisis should:
1) Be visible;
2) Set clear tasks and expectations;
3) Keep expectations real;
4) Use the extended leadership team;
5) Invest in retention;
6) Track progress-communicate any change of direction. 


\section{Trends Before and After Financial Crises}

Taxes matter for the economy because they provide sustainable funding needed for social programs and public investments to promote economic growth and development and build a prosperous and orderly society. But, policy makers face a difficult challenge in formulating good tax policies: they need to find the right balance between raising revenue and ensuring that tax rates and the administrative burden of tax compliance do not deter participation in the system or discourage business activity. The balancing act is incentive during periods of crisis. In an economic downturn some categories of public spending may automatically rise, putting pressure on deficits. Governments may at times need to deliver tax-based stimulus packages while also providing reassurance to markets that deficits will be reversed and public debt contained. Fiscal measures were part of the policy toolkit that governments brought to bear in supporting the recovery. Policy makers in most economies applied measures aimed at improving revenue collection while keeping the taxes levied on business and households as low as possible, trying to strike a balance between reducing the disincentive effects of high taxes and generating adequate resources to fund essential expenditures. Government generally reduced the rates and broadened the base for corporate income tax while increasing the rates for the consumption tax or value added tax (VAT).

In the European Union, for example, most member countries raised personal income tax rates-often temporarily, though general surcharge or through solidarity contributions from high income earners. In addition, several EU members reduced their corporate income tax bases. Most of these changes were aimed at providing tax relief for investment in physical capital or research and development while limiting the deductibility of other items. By contrast, EU members commonly increased VAT rates along with statutory rates for energy and environmental taxes and for alcohol and tobacco taxes. Some governments opted to broaden the VAT to goods and services that had previously been subject to a zero rate. Unifying VAT rates across all goods and services increases revenue and reduces compliance and administrative costs.

Along with falling revenue, the global financial and economic crisis also led to growing tax compliance risks in some economies. Compliance with tax obligations and collection of tax revenue are important to support social programs and services, for example, but in an economic downturn businesses tend to underreport tax due, fail to file their tax returns on time and even engage in transactions in the informal sector. Many economies redesigned their tax systems during that period with the objective of easing compliance with tax obligations.

Two other indicators measure the complexity of an economy's tax compliance system. The number of payments reflects the total number of taxes and contributions paid the method of payment, and the number of agencies involved. The time indicator measures the hours per year required to comply with 3 major taxes: corporate income tax, labor taxes and mandatory contributions, and VAT or sales tax. The indicators show that for businesses around the world, paying taxes became easier and less costly over the 9 years from 2004 through 2012.

Globally, the total tax rate for the doing business case study company overaged $43.1 \%$ of commercial profit in 2012. Over the 9-year period ending that year, the average total tax rate fell by 9.1 percentages points-around 1 percentage point a year. Its rate of decline was fastest during the crisis period (2008-2010), averaging 1.8 percentage points a year, then started slowing in 2011. The total tax rate fell by an average of 0.30 percentage points in 2011. The average rate for all 3 types of taxes included in the total tax rate-profit, labor and other taxes-also fell over the 9 years. Other taxes decreased the most, by profit taxes. The main driver of the drop in other taxes was the replacement of the cascading sales tax with VAT by a number of economies, many of them in Sub-Saharan Africa. Seven economies made this change during the 9 years 6 of them during the crisis period. This shift substantially reduces the tax cost for businesses while a cascading sales tax is a turnover tax applied to the full value at every stage of production, a VAT is imposed only on the final consumers bear the burden.

While the total tax rate fell in all regions over the 9-year period, Sub-Saharan Africa had the biggest decline. Its average total tax rate dropped by almost 17 percentage points between 2004 and 2012. This aligned the region more closely with the rest of the world, though its average total tax rate still remains the highest at $53.4 \%$ in 2012. In addition, many African economies lowered rates for the profit tax, reducing its share in the total tax rate. The size of the tax cost for businesses matters for investment and growth. Where taxes are high, businesses are more inclined to opt out of the formal sector.

\section{Conclusion}

Generally, business is the ability to initiate action, to take action in order to achieve certain goals, with willingness to accept accompanying risks, and to fight against all obstacles and unforeseen difficulties (Dragičević, 1994). An entrepreneur must possess talent, great will, very good education and continuous vocational training (Marković et al., 2011; Mugableh, 2013; Mugableh, 2015a; Mugableh, 2015b). A modern 
entrepreneur must start from customers, from market research, and not from production lines. The modern approach to business is based on the customer and from him back to production or procurement, depending on the type of the business. To have a successful business in economic crisis, the business must be innovative, modern, and designed in a way that offers something new, different, and better. The interactive relationship between the enterprise and its environment becomes a key point as suggested by (Phillips, 2011) and the orientation of the enterprise towards external environment should be the major preoccupation. Enterprises and business should adapt to changes in environment, respond to changes in environment, respond to market demand, and in this way fight crisis.

Today, after collapse of global economy, almost everybody is telling that the need for regulation or at least for more regulation than was the case before the economic crisis exists (Stiglitz, 2010). The crisis would be less frequent, less expensive, and the costs of the regulation would be lower. Again, in theory, markets were supposed to provide discipline, but in today's dynamic world, the discipline of the market is compromised. However, our epoch is still the closest to the dream of general leap of humanity from rule needs to rule of freedom thanks to modern economic science (Medema \& Samuels, 1996).

\section{References}

Adizes, I. K. (2009). How to manage in times of crisis. California: Adizes Institute Publications.

Adizes, I. K. (2011). Insights on policy. California: Adizes Institute Publications.

Brūmerhoff, D. (1996). Finanzwissenschaft. Mūnchen: Oldenbourg Verlag.

Dollinger, M. (1999). Entrepreneurship: Strategies and resources (2nd ed.). New Jersey: Prentice Hall.

Dragičević, A. (1994). Politička ekonomija informacijskog društva. Zagreb.

Eeckhoudt, L., Thomas, A., \& Treich, N. (2011) Correlated risks and the value of information. Journal of Economics, 102(1). Vienna: Springer.

Fredrickson, F. (2012). Seven strategies for doing business in times of crisis. Forbes, $19^{\text {th }}$ Dec. Retrieved from http://www.forbes.com/sites/fabiennefredrickson/2012/12/19/seven-strategies-for-doing-business-in-times-o f-crisis/

Krugman, P. (2012). End this depression now. New York and London: W.W. Norton Norton \& Company.

Levy, N. S. (1998). Managing high technology and innovation. London: Prentice Hall.

Marković, D., Ilić, B., Komazec, S., Ristić, Ž., \& Radovanović, D. (2011). Globalna ekonomija i geofinansije. Beograd: EtnoStil.

Medema, S. G., \& Samuels, W. J. (1996). Foundations of research in economics: How do economists do economics? Cheltenham: Edward Elgar.

Meier, G. M., \& Stiglitz, J. E. (2001). Frontiers of development economics: The future in perspective. Oxford: Oxford University Press.

Mugableh, M. I. (2013). Analysing the $\mathrm{CO}_{2}$ emissions function in Malaysia: Autoregressive distributed lag approach. Procedia Economics and Finance, 5, 571-580. http://dx.doi.org/10.1016/S2212-5671(13)00067-1

Mugableh, M. I. (2015a). Time series analysis of inward foreign direct investment function in Malaysia. Procedia-Social and Behavioral Sciences, 172, 679-685. http://dx.doi.org/10.1016/j.sbspro.2015.01.419

Mugableh, M. I. (2015b). Economic growth, $\mathrm{CO}_{2}$ emissions, and financial development in Jordan: Equilibrium and dynamic causality analysis. International Journal of Economics and Finance, 7(7), 98-105. http://dx.doi.org/10.5539/ijef.v7n7p98

OECD. (2009). The impact of the global crisis on SME and entrepreneurship: Financing and policy responses. Paris: OECD.

Pearson, C. (2002). A bluepoint for crisis management. Ivey Business Journal.

Phillips, F. Y. (2001). Market-oriented technology management. Berlin: Springer. http://dx.doi.org/10.1007/978-3-662-08500-4

Rhodes, D., \& Stelter, D. (2010). Accelerating out of the great Recession: How to win in a slow-growth economy. New York: Mc Graw Hill.

Riderstrale, J., \& Nordstrom, K. (1999). Funky business. Stockholm: Buck House Publishing.

Stiglitz, J. E. (2010). Freefall-America, free markets and the sinking of the world economy. New York: W.W. 
Norton \& Company.

Trivedi, C., \& Stokols, D. (2011). Social enterprises and corporate enterprises: Fundamental differences and defining features. Journal of Entrepreneurship, 20(1). http://dx.doi.org/10.1177/097135571002000101

Wickham, P. A. (2011). Strategic entrepreneurship (2nd ed.). London: Prentice Hall.

Zhao, J., Tennyson, R., Turro, L., \& Ordonz de Pablos, P. (2014). Knowledge management for competitive advantage during economic crisis. Pennsylvania: IGI Global.

\section{Copyrights}

Copyright for this article is retained by the author(s), with first publication rights granted to the journal.

This is an open-access article distributed under the terms and conditions of the Creative Commons Attribution license (http://creativecommons.org/licenses/by/3.0/). 